\title{
Artikel
}

\section{Samenwerkingsverbanden en de strafrechtspleging}

Prof. mr. M.J.J.P. Luchtman*

\section{Inleiding}

Gegevensuitwisseling tussen actoren binnen en buiten de strafrechtspleging is er altijd geweest. Toch heeft het fenomeen weinig aandacht gekregen. Dat lijkt de laatste tijd te veranderen. Het aantal memoranda of understanding, convenanten of andere overeenkomsten met bestuurlijke handhavers dat - onder de belofte niet buiten de bestaande wettelijke kaders te treden - de verhoudingen tussen partners nader normeert, is de laatste twee decennia fors gegroeid. Meer of minder geformaliseerde initiatieven als het Financieel Expertise Centrum (FEC), ${ }^{1}$ Regionale Informatie en Expertise Centra (RIECs) of de landelijke variant ervan (LIEC), ${ }^{2}$ de Infobox voor Crimineel en Onverklaarbaar Vermogen (iCOV), ${ }^{3}$ het Samenwerkingsprotocol ACMFIOD-OM, ${ }^{4}$ dan wel ad hoc verbanden in het kader van patserprojecten of bouwfraude ${ }^{5}$ illustreren allemaal het grote maatschappelijke belang van die samenwerking. Deze ontwikkeling kan ook niet los worden gezien van het veranderende denken over de rol en plaats van de strafrechtspleging in wat nu de geintegreerde handha-

Prof. mr. M.J.J.P. Luchtman is hoogleraar Transnationale rechtshandhaving en fundamentele rechten aan de Universiteit Utrecht.

1. Convenant FEC 2014 (Stcrt. 2014, 2351) en het bijhorende Informatieprotocol FEC 2019 (Stcrt. 2019, 20749).

2. Zie 'RIEC-LIEC convenant, Privacyprotocol en persoonsgegeven', geraadpleegd op 15 juli 2020 via https://www.riec.nl/maatregelen-endocumenten/convenant.

3. Convenant iCOV 2018 (Stcrt. 2019, 11302).

4. Stcrt. 2015, 10250

5. Zie daarover Rb. Rotterdam 9 juni 2005, ECLI:NL:RBROT: 2005:AT7246. vingsketen heet, aangestuurd door 'slimme interventies', waarin het strafrecht 'betekenisvol' wordt ingezet. In deze visie is het strafrecht geen ultimum remedium, maar een optimum remedium. ${ }^{6}$

Niet alleen de wetenschap, maar ook de wetgever heeft lang gewacht met, dan wel diep nagedacht over de normering van deze vormen van handhavingssamenwerking. $\mathrm{Na}$ een lange periode van voorbereiding werd afgelopen voorjaar een wetsvoorstel voor 'gegevensuitwisseling in samenwerkingsverbanden' (hierna ook: WGS) ingediend, waarin kaders worden geboden voor multilaterale samenwerking in het kader van, kort gezegd, de bestrijding van ongewenste maatschappelijke fenomenen, in het bijzonder ook de bestrijding van fraude. ${ }^{7}$ Wat daarbij opvalt is dat het wetsvoorstel het fenomeen van samenwerking uitsluitend benadert als een privacy-gerelateerde aangelegenheid; het voorstel richt zich op de normering van gegevensstromen, in het bijzonder persoonsgegevens. De regering heeft, zoals hieronder nog zal blijken, heel duidelijk gemaakt dat men het voorstel wat haar betreft vooral niet groter moet maken dan dat. In het voorstel worden géén nieuwe

6. VgI. M.F.H. Hirsch Ballin, 'Overbrugging van procedurele breuklijnen bij een integrale aanpak van criminaliteit', Tijdschrift voor Bijzonder Strafrecht \& Handhaving 2019, p. 163-172. Zie verder J.M.W. Lindeman, Officieren van justitie in de 21e eeuw: Een verslag van participerend observatieonderzoek naar de taakopvatting en taakinvulling van officieren van justitie (diss. Utrecht), p. 78 e.v.; J.H. Crijns, 'Vervolging en berechting' in: F.G.H. Kristen et al. (red.), Biizonder strafrecht: strafrechtelijke handhaving van sociaal-economisch en fiscaal recht in Nederland, Den Haag: Boom juridisch 2019, p. 612 e.v.

7. Regels omtrent gegevensverwerking door samenwerkingsverbanden (Wet gegevensverwerking door samenwerkingsverbanden), Kamerstukken II 2019/20, 35 447, nr. 1-4. Zie ook Kamerstukken /I 2014/15, 32 761, nr. 79, alsmede het daarbij gevoegde rapport van de Werkgroep Verkenning kaderwet gegevensuitwisseling 'Kennis delen geeft kracht'. 
autoriteiten geintroduceerd in het handhavingslandschap. Evenmin worden de taken van bestaande autoriteiten geherdefinieerd of de grenzen tussen toezicht en opsporing herijkt. ${ }^{8}$

Uiteraard moeten de kaders voor gegevensuitwisseling duidelijk zijn. ${ }^{9}$ De intensiteit van en mate waarin de vele overheidsinstanties van verschillend pluimage operationele samenwerking zoeken, werpt echter nog veel meer vragen op die in dit wetsvoorstel niet worden belicht. In dit artikel kijk ik verder dan het kader dat de wet zal bieden en beargumenteer ik dat er voor het type samenwerking dat hier aan de orde is nog veel meer werk te verrichten is, niet alleen door de wetgever, maar ook door de samenwerkende autoriteiten en de rechterlijke macht. Mijn stelling is dat juist omdat men zo min mogelijk in het bestaande handhavingslandschap wil wijzigen, de vele verschillende taken, bevoegdheden en procedures van de aldus met elkaar verbonden geraakte autoriteiten elkaar wederzijds gaan beïnvloeden. ${ }^{10}$ Dat heeft, naar ik meen, zowel gevolgen voor een aantal rechten die individuen in strafzaken toekomen, als voor de manier waarop rechtsbescherming wordt geboden tegen onregelmatigheden in de onderzoeksfase van ieder van die autoriteiten. Ik sluit zelfs niet uit dat de gekozen benadering uiteindelijk als de spreekwoordelijke boemerang terugslaat op de wens om te komen tot een effectievere rechtshandhaving.

Ik begin deze bijdrage met een overzicht van de bestaande mogelijkheden tot multilaterale samenwerking, met de nadruk op samenwerking door middel van convenanten (paragraaf 2). In paragraaf 3 bespreek ik de uitgangspunten en belangrijkste elementen van het wetsvoorstel. Daarna presenteer ik in paragraaf 4 een alternatieve kijk op het wetsvoorstel. Centraal staat daar de vraag in hoeverre het mogelijk is om te spreken van geïntegreerde handhaving en gezamenlijke verwerkingsdoeleinden zonder aandacht te besteden aan de rechtspositie van de onderzochte personen. Ik concentreer me daarbij op het nemo tenetur-beginsel en het leerstuk van het onrechtmatig bewijs. Ik sluit af met enige observaties en aanbevelingen (paragraaf 5).

Tot slot, omdat de bescherming van persoonsgegevens in het kader van dit wetsvoorstel in een volgend nummer van dit tijdschrift aan de orde zal komen, besteedt deze bijdrage daaraan slechts zijdelings aandacht. Evenmin richt ik me op de positie van private actoren in deze samenwerkingsverbanden; ik concentreer me op de samenwerking tussen de straf- en bestuursrechtelijke

8. Dat punt komt herhaaldelijk terug in de memorie van toelichting, vgl. Kamerstukken I/ 2019/20, 35 447, nr. 3, p. 17 (MvT).

9. Zie verder uitvoerig A.J.C. de Moor-van Vugt e.a., Gegevensuitwisseling door toezichthouders, Amsterdam: Universiteit van Amsterdam 2012 en ook M. Luchtman, J. Vervaele \& O. Jansen, Informatie-uitwisseling in het kader van het Financieel Expertise Centrum, Utrecht: Utrecht University Repository 2002

10. Dat is een variant op de kritiek die de Raad van State ook al op een eerder ontwerp van het voorstel had, zie Kamerstukken // 2019/20, 35 447 , nr. 4, p. 16-17 handhavingskolom. De nadruk ligt op de samenwerkingsverbanden in de sociaal-economische hoek.

\section{Het huidige kader voor multilaterale gegevens- uitwisseling}

\subsection{Convenanten en gegevensuitwisseling}

Het juridisch kader voor gegevensuitwisseling tussen overheidsdiensten wordt momenteel gevormd door de AVG, de Wet justitiële en strafvorderlijke gegevens (WJSG) of de Wet politiegegevens, de geheimhoudingsplichten waaraan de deelnemende instanties zijn gebonden en ook de bevoegdheden die deze instanties hebben om voor onderzoeksdoeleinden (toezicht of opsporing) gegevens op te vragen, ook bij andere overheidsinstanties.

Binnen dit wettelijk kader spelen convenanten een belangrijke rol. ${ }^{11}$ De huidige wettelijke kaders zijn op onderdelen nog open en onbepaald. Convenanten kunnen helpen om op basis van wederkerigheid duidelijkheid te scheppen over bijvoorbeeld de nadere precisering van het doel van het samenwerkingsverband, de vorm waarin de informatieverstrekking plaatsvindt (alleen op verzoek, ook spontaan en/of automatisch) of de voorwaarden waaronder gegevens mogen worden gebruikt of aan derden mogen worden verstrekt (bijvoorbeeld het GAZO-principe). ${ }^{12}$ Het convenant biedt daarbij ook ruimte om afspraken te maken over de bijzonderheden die op bepaalde beleidsterreinen spelen, zoals bijvoorbeeld de inkeerbepaling in het fiscale recht, het clementiebeleid in het mededingingsrecht of, in de financiële sector, het bankgeheim. Niet zelden hebben de specifieke regels ter zake een Europeesrechtelijke achtergrond.

Met het maken van dergelijke afspraken kunnen convenantpartners uiteraard niet buiten de wettelijke kaders treden. Iedere deelnemende instantie zal dus telkens opnieuw moeten beoordelen in hoeverre het op haar toepasselijke wettelijke kader gegevensverstrekking aan een andere partij toestaat, dan wel in hoeverre de verdere verwerking van gegevens die zij via het samenwerkingsverband ontvangt verenigbaar is met haar eigen taak. Dat hangt onlosmakelijk samen met rechtsstatelijke beginselen als het specialiteitsbeginsel, het verbod van détournement de pouvoir en de bescherming van persoonsgegevens.

Binnen de bestaande wettelijke mogelijkheden zijn er grofweg drie manieren waarop gegevens kunnen worden verstrekt. Een dergelijke verstrekking is allereerst

11. Kritisch daarover: A.J.C. de Moor-van Vugt e.a., Gegevensuitwisseling door toezichthouders, Amsterdam: Universiteit van Amsterdam 2012 p. 11, 14, 29-30.

12. GAZO betekent 'geen actie zonder overleg'. 
mogelijk wanneer de verstrekking van de gegevens in lijn is met de eigen taakopdracht van de verstrekkende instantie. Zo is sinds jaar en dag bekend dat onder de 'uitvoering van de belastingwet' als bedoeld in artikel 67 AWR ook de opsporing en vervolging van fiscale delicten valt. ${ }^{13}$ Dat verstrekking mogelijk is, wil dan overigens nog niet zeggen dat deze ook moet plaatsvinden. Daarnaast is het mogelijk dat op een wettelijke geheimhoudingsplicht bij wet uitzonderingen worden toegelaten. Die uitzonderingen kunnen open zijn geformuleerd, zoals in artikel 2:5 Awb, of juist heel specifiek, zoals de uitzonderingen op artikel 1:89 Wft. Hoe dwingender de formulering van de betreffende geheimhoudingsbepaling, des te moeilijker de mogelijkheden tot samenwerking in multilateraal verband. Het is ten derde mogelijk dat een geheimhoudingsregime weliswaar niet voorziet in de mogelijkheid van verstrekking, maar dat er een vorderingsbevoegdheid tegenover wordt gesteld die na een afweging van belangen zwaarder weegt dan het belang van geheimhouding. Voorbeelden zijn artikel 55 AWR of de strafvorderlijke uitleverings- en inbeslagnemingsbevoegdheden. Het is voorgekomen dat het Openbaar Ministerie die bevoegdheden ook daadwerkelijk heeft ingezet, tegen DNB, in het kader van het zogenaamde Clickfondsonderzoek van eind jaren negentig. ${ }^{14}$

In een iets andere, recentere setting speelden de strafvorderlijke opsporingsbevoegdheden en dwangmiddelen ook een rol toen een aantal rechtbanken de verstrekking door convenantpartners van gegevens uit eigen beweging aan het OM onrechtmatig achtte, omdat dat niet in lijn zou zijn met de systematiek van de Wet bevoegdheden vorderen gegevens. De gedachte was, kort gezegd, dat persoonsgegevens die worden opgevraagd voor strafvorderlijke doeleinden alleen kunnen worden verkregen met toepassing van de bij die wet gecreëerde strafvorderlijke bevoegdheden, in het bijzonder artikel 126nd $\mathrm{Sv}$ (inclusief een redelijke verdenking). ${ }^{15}$ Daarmee werd een bom onder de convenantenaanpak gelegd, omdat die nu juist staat of valt met de mogelijkheid van spontane informatie-uitwisseling en wederzijdse verrijking van de informatiepositie. Uiteraard is daaraan grote behoefte, juist in de fase vóór de redelijke verdenking als in artikel 27 Sv. Inmiddels heeft de Hoge Raad hier duidelijkheid verschaft. Voor samenwerking tussen overheidsinstan- ties, en in het bijzonder de verstrekking van gegevens aan het OM, is niet per se een artikel 126nd-vordering nodig, ${ }^{16}$ net zomin overigens als voor verstrekking van strafvorderlijke gegevens aan de belastinginspecteur een vordering als in artikel 55 AWR nodig is. ${ }^{17}$ Dat lijkt mij ook een juiste uitkomst te zijn.

Uit het voorgaande blijkt al dat samenwerking in convenant-verband in veel opzichten een gecompliceerde aangelegenheid is, waarin iedere deelnemende instantie aan andere regels is gebonden. Dat zorgt voor onduidelijkheid, niet in het minst bij de deelnemende partijen zelf. Zo was in de begindagen van het FEC een telkens terugkerend discussiepunt in hoeverre de financiële toezichthouders informatie mochten verstrekken aan de politie en OM, alsmede de belastingdienst. ${ }^{18}$ De achtergrond daarvan lag in Europese regelgeving die nadrukkelijk tot doel had het bankgeheim van de onder toezicht gestelde instellingen te beschermen. Vanwege de onduidelijkheid over de geldende regels, die niet alleen in het FEC aan de orde is, worden informatieverstrekkingen aan het OM ook nu nog niet zelden 'geformaliseerd' door ex post - na verstrekking - alsnog een vordering ex artikel 126nd Sv te doen. Dat is niet alleen onnodig formalistisch, bovendien roept die praktijk vragen op, omdat ze - ook wanneer er wel een geldige verstrekkingsgrondslag was - de indruk wekt dat onrechtmatigheden achteraf moesten worden hersteld.

Ook de rechterlijke macht weet zich niet altijd goed raad met de problematiek van gegevensuitwisseling en convenanten. Aan de ene kant van het spectrum zien we uitspraken waarin wordt geaccepteerd dat het niet naleven van de regels omtrent informatieverstrekking kan worden gerepareerd door het achteraf alsnog verlenen van toestemming daarvoor. ${ }^{19}$ De belastingkamer van de Hoge Raad aanvaardde in een andere zaak bovendien dat de precieze wettelijke basis voor de verstrekking van strafvorderlijke gegevens aan de belastingdienst in het midden werd gelaten. ${ }^{20}$ Ook hebben rechterlijke colleges toegestaan dat onrechtmatigheden bij de verstrekking van gegevens aan de zijde van de verstrekker geen gevolgen hadden voor het gebruik van die informatie aan de zijde van de ontvanger. ${ }^{21}$ Die laatste viel, zo was de redenering, immers niets aan te rekenen.

13. Vgl. HR 26 april 1988, ECLI:NL:HR:1988:AD5708, NJ 1989, 390 m.nt. Van Veen.

14. Rb. Amsterdam 5 oktober 2000, JOR 2000/244. Deze zaak leidde uiteindelijk tot de introductie van art. 1:92 lid $2 \mathrm{Wft}$. Zie verder ook Rb. Amsterdam 29 november 2007, ECLI:NL:RBAMS:2007:BB9689; HR 22 juli 1986, NJ 1986, 823; alsmede HR 4 januari 2000, NJ 2000, 537.

15. Bijvoorbeeld in Rb. Oost-Brabant 18 januari 2016, ECLI:NL:RBOBR: 2016:139. Een coherente lijn hierover bestond overigens niet, noch in het oordeel over de onrechtmatigheid, noch over de daaraan te verbinden sanctie; zie verder namelijk Rb. Rotterdam 22 juli 2010, ECLI:NL:RBROT:2010:BN3336 (camerabeelden RET); Rb. Utrecht 26 augustus 2011, ECLI:NL:RBUTR:2011:BR5923 (Hennep), teruggedraaid door Hof Arnhem-Leeuwarden 8 november 2013, GHARL:2013:8478. Zie ook Rb. Zwolle 1 juni 2011, ECLI:NL:RBZLY:2011:BR4808 (Project ongebruikelijk bezit) en Rb. Utrecht 23 december 2011, ECLI:NL:RBUTR:2011:BV0123. Zie verder: Ballin, NJB 2016/1342, p. 1902.

16. HR 18 juni 2019, ECLI:NL:HR:2019:857 (Handhavingsconvenant regio IJsselland), voorafgegaan door Hof Arnhem-Leeuwarden 1 maart 2017, ECLI:NL:GHARL:2017:1719. Dat kon ook al worden afgeleid uit HR 31 januari 2012, ECLI:NL:HR:2012:BT7126 en vooral uit HR 13 november 2012, ECLI:NL:HR:2012:BX8079.

17. HR 21 december 2018, ECLI:NL:HR:2018:2389.

18. Daarover uitvoerig: M. Luchtman, J. Vervaele \& O. Jansen, Informatieuitwisseling in het kader van het Financieel Expertise Centrum, Utrecht: Utrecht University Repository 2002, p. 26-43.

19. Rb. Rotterdam 9 juni 2005, ECLI:NL:RBROT:2005:AT7246 (Bouwfraude).

20. HR 21 december 2018, ECLI:NL:HR:2018:2389.

21. Rb. Rotterdam 9 juni 2005, ECLI:NL:RBROT:2005:AT7246 (Bouwfraude). Vgl. ook CBb 22 februari 2017, ECLI:NL:CBB:2017:46, onder 5-7; CBb 9 juni 2015, ECLI:NL:CBB:2015:193, onder 4.11. 
Aan de andere kant zijn er ook rechters die juist erg strikt in de leer zijn. In een later op dat punt vernietigde uitspraak oordeelde de Rechtbank Rotterdam de verstrekking van tapgegevens aan de mededingingsautoriteit onrechtmatig omdat er geen kenbare, voor de rechter toetsbare afweging van belangen had plaatsgevonden. ${ }^{22}$ Volgens de rechtbank had de ACM zich, alvorens gebruik te maken van deze gegevens, ervan dienen te vergewissen dat en waarom de officier van justitie van oordeel was dat sprake was van een zwaarwegend maatschappelijk belang en waarom de verstrekking met het oog daarop noodzakelijk was. De uitspraak werd later echter vernietigd door het $\mathrm{CBb}$. Dat overwoog dat in het geval van verstrekking van tapgegevens aan bestuursorganen als de ACM rechterlijke toetsing is geborgd voorafgaand aan de tap (art. 126m Sv), terwijl rechtsbescherming tegen de verstrekking ervan openstaat in kort geding of in de latere rechterlijke toetsing van het (boete)besluit waaraan de tapgegevens ten grondslag zijn gelegd. ${ }^{23}$ De ACM mag er daarbij in beginsel vanuit gaan dat het $\mathrm{OM}$ de kaders van de WJSG en de daarop gebaseerde Aanwijzing in acht neemt. Aldus wordt duidelijk dat de bestuursrechter zichzelf weliswaar een residuale toetsingsbevoegdheid van de rechtmatigheid van de verstrekking door het $\mathrm{OM}$ toebedeelt, maar zich vooral richt op de rechtmatigheid, zorgvuldigheid en subsidiariteit van het handelen van de ACM zelf bij de verkrijging en het verdere gebruik van de gegevens door de laatste. Opvallend is dat daarbij klaarblijkelijk niet relevant is dat de laatste op meerdere momenten vóór de formele verstrekking (en zelfs nog vóór de formele opening van het ACM-onderzoek) al inzage in (de bulk van) de tapgegevens had verkregen. ${ }^{24}$

\subsection{Samenwerkingsverbanden op het snijvlak van toezicht en opsporing}

Naast vragen over geheimhouding, doelbinding en de daaraan gekoppelde rechtsbescherming - alle sterk gerelateerd aan de omschrijving van het beleidsmatige taakveld van de betrokken deelnemers - kunnen er, zoals uit het voorgaande ook al duidelijk werd, problemen rijzen die te maken hebben met de verschillende soorten bevoegdheden die de deelnemers tot hun beschikking hebben. Dat speelt in het bijzonder voor die verbanden waarin bestuursrechtelijke autoriteiten en justitiële autoriteiten met elkaar samenwerken. Het werpt als gezien de vraag op of tapgegevens mogen worden verstrekt aan bestuursorganen, die zelf niet over tapbevoegdheden beschikken, maar ook of onder dwang verkregen informatie mag worden verstrekt aan het $\mathrm{OM}$ en mag worden gebruikt in de strafzaak tegen de verdachte, als bewijs of anderszins.

23. CBb 9 juni 2015, ECLI:NL:CBB:2015:193; zie ook Pres. Rb. Den Haag 26 juni 2009, ECLI:NL:RBSGR:2009:BJ0047. De zaak ligt nu in Straatsburg, zie EHRM Janssen de Jong Groep NV [e.a.] t. Nederland, appl. nrs. 2800/16. Ook de Hoge Raad eist geen schriftelijke verslaglegging van de verstrekking van strafvorderlijke gegevens, zie opnieuw HR 21 december 2018, ECLI:NL:HR:2018:2389.

24. Zie immers r.o. 4.11 van de uitspraak.
Er zijn geen aanwijzingen dat de verstrekking van dergelijke gegevens binnen samenwerkingsverbanden op een andere manier wordt benaderd dan de incidentele, bilaterale verstrekking van dergelijke gegevens tussen overheidsdiensten buiten die context. Dat past ook in de gedachtegang dat convenanten op zichzelf niets wijzigen aan de bestaande wettelijke kaders. De controle op de rechtmatigheid van de gegevensverwerking is daarin als het ware verdeeld naar afzonderlijke handeling. Waar de vergaring van de gegevens een inbreuk op bijvoorbeeld artikel 8 EVRM of artikel 7 van het Handvest van de grondrechten van de Europese Unie (hierna 'EU Handvest') kan opleveren, kan de verstrekking van aldus verkregen persoonsgegevens op haar beurt een nieuwe inbreuk op dat artikel vormen die een afzonderlijke grondslag behoeft. ${ }^{25}$ Die wordt dan geboden door de AVG, de Wet justitiële en strafvorderlijke gegevens of de Wet politiegegevens. Hetzelfde geldt voor de daaropvolgende verstrekking of doelafwending na verwerking.

Eenmaal rechtmatig verkregen (persoons)gegevens worden dus - tenzij er bijzondere doelbeperkingen gelden - allemaal volgens hetzelfde regime behandeld, ongeacht de wijze waarop ze zijn verkregen. ${ }^{26}$ Ook wanneer de informatie in eerste instantie op onrechtmatige wijze werd verkregen of op onrechtmatige wijze werd doorgegeven, staat dat naar Nederlands recht op zichzelf niet in de weg aan een later gebruik voor andere doeleinden. Dat is alleen anders wanneer dat gebruik zozeer indruist tegen wat van een behoorlijk handelende overheid mag worden verwacht dat het onder alle omstandigheden ontoelaatbaar moet worden geacht. ${ }^{27} \mathrm{Ik}$ kom daarop nog terug.

Ook artikel 6 EVRM of artikel 47 en 48 EU Handvest kunnen een rol spelen bij gegevensuitwisseling onder convenanten en ook hier zijn er geen aanwijzingen dat de problematiek anders zal worden benaderd dan onder incidentele en/of bilaterale gevallen van informatie-uitwisseling. Het gaat dan in het bijzonder om het nemo tenetur-beginsel en de daaraan verwante rechten als het recht op toegang tot een raadsman. Dat geldt niet alleen wanneer er gegevens worden uitgewisseld over personen die reeds verdachte zijn en dus aanspraak maken op die verdedigingsrechten, maar ook wanneer gegevens over personen worden opgewerkt tot de basis voor een opsporingsonderzoek of een verdenking.

Wat betreft gegevensuitwisseling over personen die reeds verdachte zijn, rijst in het bijzonder de vraag of toezichtbevoegdheden nog wel mogen worden toegepast

25. Vgl. EHRM 26 maart 1987, ECLI:CE:ECHR:1987:0326JUD000924881 (Leander t. Zweden); EHRM 29 juni 2006, ECLI:CE:ECHR: 2006:0629DEC005493400 (Weber en Saravia t. Duitsland), par. 79 en 125.

26. Daarmee is niet gezegd dat de intensiteit van de toetsing ook altijd dezelfde is. Het CBb toetst bijvoorbeeld in CBb 9 juli 2015, ECLI:NL:CBB:2015:193, r.o. 4.9-4.11, zoals in de WJSG voorgeschreven, aan het subsidiariteitsbeginsel. De verwerking van tapgegevens door de AFM was geoorloofd, omdat er geen mildere alternatieven waren.

27. VgI. HR 20 maart 2015, ECLI:NL:HR:2015:643. 
zonder daarbij de aan de verdachte als zodanig toekomende waarborgen in acht te nemen. Dat laatste is, zoals bekend, in ieder geval niet toegestaan wanneer toezichten opsporingsbevoegdheden binnen één persoon zijn verenigd; in dat geval moeten de strafvorderlijke waarborgen direct worden toegepast. ${ }^{28}$ Van een dergelijke personele unie van taken is bij samenwerkingsverbanden natuurlijk geen sprake. Niettemin wordt met convenanten wel een zekere mate van functionele verbondenheid van procedures bewerkstelligd. In die gevallen blijft de medewerkingsplicht in niet-punitieve procedures overeind. Wanneer aldus in de niet-punitieve procedure daadwerkelijk dwang wordt uitgeoefend, ${ }^{29}$ en niet kan worden uitgesloten dat wilsafhankelijk materiaal tevens in verband met een 'criminal charge' tegen de belastingplichtige zal worden gebruikt, moeten de autoriteiten waarborgen dat de belastingplichtige zijn recht om niet mee te werken aan zelfincriminatie effectief kan uitoefenen. Aangezien hierop gerichte regelgeving in Nederland ontbreekt, dient de rechter - maar dit geldt, naar ik aanneem, voor alle betrokken autoriteiten - in de vereiste waarborgen te voorzien. Dat kan deze doen door een gebruiksrestrictie op te leggen die inhoudt dat het verstrekte materiaal uitsluitend wordt gebruikt ten behoeve van de belastingheffing. ${ }^{30}$ Een gebruiksrestrictie is in die gevallen dus noodzakelijk, wil althans de betrokkene zonder schending van artikel 6 EVRM tot medewerking gehouden kunnen worden wat betreft het niet-punitieve deel van het onderzoek. ${ }^{31}$

226 De lijn van de Hoge Raad lijkt op die van het EHRM. In Chambaz $t$. Zmitserland ${ }^{32}$ kwam de laatste immers al tot de conclusie dat de punitieve tak van artikel 6 EVRM van toepassing kan zijn op een fiscale navorderings- of naheffingsprocedure, zelfs wanneer het strafrechtelijk onderzoek pas jaren later wordt gestart en beide procedures formeel van elkaar gescheiden zijn. ${ }^{33}$

28. Vgl. HR 26 april 1988, ECLI:NL:HR:1988:AD5708, NJ 1989, 390 m.nt. Van Veen; HR 1 november 2016, ECLI:NL:HR:2016:2454; HR 20 februari 2018, ECLI:NL:HR:2018:247.

29. Uiteindelijk is de maatstaf immers dat de mate van 'compulsion' in de woorden van het EHRM niet 'improper' mag worden; niet alle vormen van dwang of druk zijn ontoelaatbaar; vgl. EHRM 29 juni 2007, ECLI:NL:XX:2007:BB3173 (O'Halloran en Francis $t$. VK) en HR 21 maart 2008, ECLI:NL:HR:2008:BA8179, r.o. 3.3.3; HR 8 augustus 2014, ECLI:NL:HR:2014:2144, r.o. 2.6

30. HR 12 juli 2013, ECLI:NL:HR:2013:BZ3640; waarover ook EHRM 16 juni 2015, ECLI:CE:ECHR:2015:0616DEC000078414 (Van Weerelt t. Nederland). Dit is ook de lijn van het CBb zie: CBb 7 mei 2019, ECLI:NL:CBB:2019:177. Zie ook HR 24 april 2015, ECLI:NL:HR: 2015:3354, NJ 2015/265 m.nt. J.W. Zwemmer.

31. Wat onder 'gebruik' wordt verstaan blijft in de rechtspraak onduidelijk; vgl. M.J. Borgers \& T. Kooijmans, 'De onderzoeksfase: toezicht, controle en opsporing,' in: F. Kristen et al. (red.), Bijzonder strafrecht: Strafrechtelijke handhaving van sociaal-economisch en fiscaal recht in Nederland, Den Haag: Boom juridisch 2019, par. 4.4.2. Gaat het om de verstrekking van gegevens, of (aan ontvangstzijde) om het gebruik als sturingsinformatie, als basis voor een verdenking, dan wel (alleen) om het gebruik als bewijs in een punitieve procedure? Over die vragen laat het EHRM zich niet uit in EHRM 16 juni 2015, ECLI:CE:ECHR: 2015:0616DEC000078414 (Van Weerelt t. Nederland).

32. EHRM 5 april 2012, ECLI:CE:ECHR:2012:0405JUD001166304 (Chambaz $t$. Switzerland)

33. Over dat Zwitserse systeem leze men M. Luchtman, Grensoverschrijdende sfeercumulatie (diss. Utrecht), Nijmegen: WLP 2007,
Het Hof prikt als het ware door die formele scheidingen heen wanneer de bevoegde autoriteiten met elkaar moeten samenwerken, over en weer informatie uitwisselen en de eigen onderzoeken afstemmen op de bevindingen en zelfs wensen van de ander. ${ }^{34}$

De mate van koppeling tussen de procedures verklaart waarom strafvorderlijke waarborgen al een rol kunnen spelen op een moment dat er nog geen verdenking of charge is. Zo bezien gaat het EHRM in Chambaz een stap verder dan in Saunders waarin werd uitgemaakt dat onder dwang verkregen, van de wil afhankelijk materiaal in beginsel niet als bewijs in een latere punitieve procedure mag worden gebruikt. In Saunders was het onderzoek van de zogenaamde DTI-inspectors op zichzelf niet het probleem, ook al stonden er strafrechtelijke sancties op niet-medewerking. Het Hof benadrukt juist de autonomie van het onderzoek van die inspecteurs ten opzichte van het latere strafrechtelijke onderzoek. ${ }^{35}$ Evenmin was de verstrekking van de gegevens aan de strafvorderlijke autoriteiten in strijd met artikel 6 EVRM. Dat was anders in Chambaz. Daar oordeelde het Hof dat het nemo tenetur-beginsel al werd geschonden toen de betrokkene met boetes werd gedwongen documenten te verschaffen voor niet-punitieve doeleinden, omdat deze niet kon uitsluiten dat die documenten ook zouden kunnen worden gebruikt voor strafvervolging. ${ }^{36}$

\section{Het wetsvoorstel gegevensverwerking door samenwerkingsverbanden}

3.1 Doelstelling en reikwijdte van de wet

Het is goed dat er nu een wetsvoorstel ligt dat algemene kaders biedt voor gegevensuitwisseling binnen samen-

p. 466-489, i.h.b. p. 474-476 en p. 479-485. Uit EHRM 21 april 2009, ECLI:CE:ECHR:2009:0421JUD001923503 (Marttinen t. Finland) lijkt bovendien te kunnen afgeleid dat het EHRM deze oplossing ook acceptabel vindt voor de situatie dat er wel al een charge is uitgebracht.

34. Para 43, 48: 'Elle estime, par conséquent, que les deux procédures étaient étroitement liées de sorte que le caractère manifestement pénal de l'enquête s'est étendu à la procédure ayant donné lieu à la présente requête.' Interessant is dat diezelfde verbondenheid - het criterium van suffisamment liées (para 43) - ook een rol speelt in 's Hofs gewijzigde interpretatie van het ne bis in idem-beginsel. Samenwerking tussen autoriteiten voor elkaar aanvullende doeleinden kan een schending van dat beginsel voorkomen, zie EHRM 15 november 2016, ECLI:CE:ECHR: 2016:1115JUD002413011 (A \& B t. Noorwegen), par. 131-134 (sufficiently connected in substance and time). Voor kritiek, juist ook in het licht van de verdedigingsrechten, leze men de dissenting opinion van Pinto de Albuquerque, par. 60-64 bij EHRM 15 november 2016, ECLI:CE:ECHR:2016:1115JUD002413011 (A \& B t. Noorwegen).

35. EHRM 17 december 1996, ECLI:CE:ECHR:1996:1217JUD001918791 (Saunders t. Verenigd Koninkrijk), par. 67. Dat is mijns inziens een belangrijk verschil met Chambaz of J.B. t. Zwitserland

36. Para 54: 'La Cour observe, par ailleurs, que le requérant ne pouvait exclure que toute information relative à des revenus supplémentaires de sources non imposées l'exposait à être accusé d'avoir commis l'infraction de soustraction d'impôt (...) et était de nature à compromettre sa position dans l'enquête pour soustraction d'impôts.' 
werkingsverbanden. De noodzaak om 'maatschappelijke vraagstukken (...) van een integrale aanpak te voorzien, waarbij verschillende instanties uit de overheid maar soms ook de private sector met elkaar samenwerken om dat vraagstuk aan te pakken', ${ }^{37}$ lijkt moeilijk te kunnen worden teruggedraaid en zou ook zonder dit voorstel krachtig zijn doorgezet. Een wettelijke regeling kan onduidelijkheden ophelderen, de informatieverschaffing verbeteren en stroomlijnen, maar ook waarborgen inbouwen waarmee individuen een betere rechtsbescherming kan worden geboden. De regering heeft ervoor gekozen om een generieke wet te introduceren waarin voor bestaande en toekomstige samenwerkingsverbanden gezamenlijke regels worden gesteld. De nieuwe wet bestrijkt daarmee niet één specifiek terrein, zoals de bestrijding van bijvoorbeeld fraude. De regering heeft bovendien oog voor de omstandigheid dat ook private partijen een toenemende rol binnen samenwerkingsverbanden spelen en definieert in dat kader ook de verantwoordelijkheden van de verschillende betrokkenen.

Op andere punten vallen de ambities evenwel tegen. Zo gaat het voorstel, net als een eerder wetsontwerp, nog steeds uit van de mogelijkheid om een samenwerkingsverband onder de reikwijdte van de wet te brengen. ${ }^{38}$ Een samenwerkingsverband dat een zwaarwegend maatschappelijk belang dient valt dus zeker niet verplicht onder de wet; de deelnemers kunnen daar zelf voor opteren (in welk geval ze vervolgens wel moeten worden aangewezen). ${ }^{39}$ Evenmin creëert het voorstel een exclusief regime voor gegevensverstrekking voor instanties die wel aan een samenwerkingsverband deelnemen. Dat staat met zoveel woorden in artikel 1.2, tweede lid, ${ }^{40}$ waarin is bepaald dat dat deelnemers ook op andere manier dan voorzien bij de WGS kunnen blijven samenwerken.

Voor die verbanden die wel onder de wet komen te vallen wordt op aanraden van de Raad van State een onderscheid gemaakt tussen de meer duurzame verbanden waarvoor in de wet zelf voorzieningen worden getroffen, ${ }^{41}$ en verbanden waarvoor de wet de kaders stelt en waarvoor nadere uitwerking bij $\mathrm{AMvB}$ plaatsvindt. Via een zogenaamde nahangprocedure kan het parlement (Eerste of Tweede Kamer) in het laatste geval echter na publicatie van de $\mathrm{AMvB}$ binnen een periode van vier weken met een absolute meerderheid verzoeken om het in de $\mathrm{AMvB}$ geregelde onderwerp bij wet te regelen. In dat geval wordt een daartoe strekkend wetsvoorstel zo spoedig mogelijk ingediend. ${ }^{42}$
Samenwerkingsverbanden die onder de wet komen te vallen zijn geen zelfstandige entiteiten; het zijn geen bestuursorganen of entiteiten met rechtspersoonlijkheid. ${ }^{43}$ Evenmin brengt de aanwijzing van een overheidsinstantie of overheidsorgaan als deelnemer aan een samenwerkingsverband een wijziging aan in de publiekrechtelijke taken en bevoegdheden van de deelnemers (art. 1.3). ${ }^{44}$ Het voorstel berust, integendeel, op de gedachte dat 'de gezamenlijke verwerking van persoonsgegevens en andere relevante gegevens ten dienste staat aan de uitoefening van de bestaande wettelijke taken en bevoegdheden van de deelnemers. ${ }^{45}$ De memorie van toelichting stelt: 'De ontwikkelingen op het terrein van ICT bieden partijen binnen de overheid immers steeds meer mogelijkheden om tot een snelle, accurate en volledige uitwisseling van informatie te komen en op grond van deze informatie analyses te maken die tot een integraal en effectief optreden leiden. ${ }^{46}$ Verderop is dan te lezen: '[V]oor zover dit wetsvoorstel regels bevat over de juridische verhoudingen tussen de deelnemers, hebben die uitsluitend betrekking op de nadere uitwerking van de eisen die de Algemene verordening gegevensbescherming stelt ter zake van de gezamenlijke verwerking, zoals de gezamenlijke verwerkingsverantwoordelijkheid,' (art. 1.4 lid 1). ${ }^{47}$ De thematiek is dus vooral ingestoken als een kwestie van gegevensverwerking.

Uit het voorgaande volgt dan ook dat, specifiek voor het snijvlak tussen toezicht en opsporing, er aan het bestaande kader weinig verandert. De samenwerkingsverbanden zelf doen immers geen onderzoek; '[h]et gaat in dit wetsvoorstel om het in kaart brengen van benodigde interventies, niet om het verrichten van daadmerkelijke interventies' [mijn cursivering]. ${ }^{48}$ Het coördinerende werk dat in het samenwerkingsverband plaatsvindt levert in deze optiek geen aantasting van rechten of vrijheden op, anders dan de uitwisseling van persoonsgegevens. Enigszins apodictisch wordt dan iets verder in de memorie van toelichting gesteld dat het voorstel ook geen afbreuk doet aan het onschuldsbeginsel. Evenzeer mist '[d]e stelling van de [Autoriteit Persoonsgegevens] dat in het strafrecht het verbod van zelfincriminatie en de presumptie van onschuld ernstig dreigen te worden gerelativeerd' grond. ${ }^{49}$ De scheiding tussen de verschillende rechtsgebieden is immers nu ook al niet absoluut, aldus de regering.

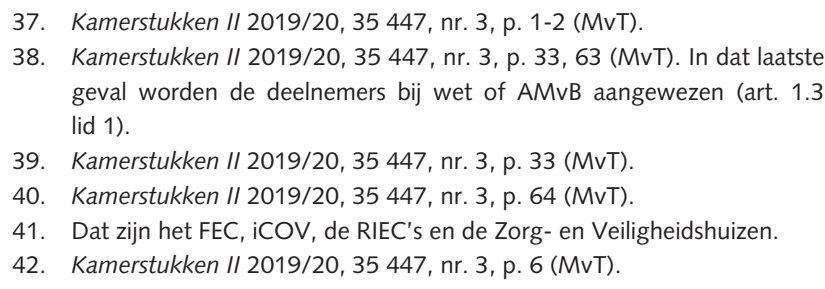






\subsection{Verstrekking aan en verwerking door samenwerkingsverbanden}

Het wetsvoorstel brengt op drie momenten verbeteringen aan in de bestaande mogelijkheden tot samenwerking. Het gaat om de mogelijkheden met betrekking tot de instroom van gegevens, de verwerking van gegevens binnen het samenwerkingsverband, en de mogelijkheden met betrekking tot de verstrekking aan derden. Op die manier bereikt de wet wat onder het huidige recht vaak ontbreekt; een uniform kader voor gegevensuitwisseling, geënt op een bij wet of $\mathrm{AMvB}$ gedefinieerd zwaarwegend maatschappelijk belang.

Met betrekking tot de instroom van gegevens bevat het voorstel belangrijke innovaties. Het definieert in de eerste plaats (de kaders voor) een gezamenlijk doel dat ook multilaterale verstrekking van gegevens mogelijk maakt. ${ }^{50}$ Het kan daarbij ook gaan om gegevens van strafrechtelijke aard (1.5 lid 3), zoals tapgegevens. Hoewel de WGS zelf niet de omvang en reikwijdte van de geheimhoudingsplichten van de deelnemende instanties doorbreekt, kent het voorstel in de tweede plaats wel een aantal flankerende bepalingen waarin voor de samenwerkingsverbanden die bij wet worden geregeld de geheimhoudingsplichten in een aantal sectorale wetten nadrukkelijk worden aangepast met het oog op de gegevensverstrekking aan dat samenwerkingsverband. Daarmee wordt ook de verstrekkingsgrondslag verduidelijkt (vgl. 1.5 lid 2). ${ }^{51}$ In de derde plaats valt op dat het wetsvoorstel, op advies van de Raad van State, uitgaat van een verstrekkingsplicht. ${ }^{52}$ Deelnemers zijn gehouden tot verstrekking als dat noodzakelijk is voor het doel van het samenwerkingsverband, tenzij zich zwaarwegende redenen daartegen verzetten (art. 1.5 lid 1).

Al deze factoren brengen met zich dat, ook al worden de taakstellingen van de deelnemende instanties zelf niet gewijzigd, de gezamenlijke doelstellingen van het samenwerkingsverband nadrukkelijk worden betrokken op de taakstellingen van zijn deelnemers, en omgekeerd. Deelname aan samenwerkingsverbanden, met name de verbanden die bij wet worden genormeerd, is niet vrijblijvend, maar heeft een verplichtend karakter. Uitzonderingen zijn mogelijk, maar alleen in zwaarwegende gevallen. Het oordeel daarover is aan de verstrekkende deelnemer gelaten.

De verruimde mogelijkheden met betrekking tot het verstrekken van gegevens maken ook het verwerken van gegevens voor gezamenlijke doeleinden mogelijk (art. 1.6). Op die manier kunnen gegevens - het voorstel spreekt van signalen (art. 1.1) - worden opgewerkt tot de aanleiding voor voornoemde 'concrete interventies'. In die vroege fase van het (fenomeen)onderzoek is afstemming dus nadrukkelijk een deel van de agenda.

50. Kamerstukken I/ 2019/20, 35 447, nr. 3, p. 10 (MvT).

51. De plaatsing van dit artikellid in het hoofdstuk met algemene bepalingen is overigens nogal merkwaardig, omdat de daar genoemde bepalingen niet voor alle samenwerkingsverbanden relevant zijn.

52. Kamerstukken // 2019/20, 35 447, nr. 3, p. 11 (MvT).
Het voorstel is niet erg duidelijk in het benoemen van het moment waarop die uitwisseling en afstemming eindigt. Is dat het geval wanneer een verdenking is gerezen? Of mag daarna ook nog steeds samenwerking plaatsvinden? Het eerste zou voorzichtig kunnen worden afgeleid uit een aantal bepalingen in het voorstel. Zo betreft de verstrekking van in het FEC verwerkte informatie aan deelnemers enkel sturingsinformatie (art. 2.8), ${ }^{53}$ hetgeen een beperking in tijd suggereert. ${ }^{54}$ In meer algemene zin, dus buiten de specifieke setting van het FEC, is steun voor die opvatting bovendien te vinden in de memorie van toelichting. Immers, '[h] $\mathrm{h}$ gaat in dit wetsvoorstel om het in kaart brengen van benodigde interventies, niet om het verrichten van daadwerkelijke interventies. In de fase van het in kaart brengen staat nog niet vast of een eventuele interventie noodzakelijk is. Evenmin is tevoren duidelijk of deze mogelijke interventie een strafrechtelijke, bestuursrechtelijke of andere aard zou hebben.' ${ }^{55}$ Toch denk ik dat daarmee niet een samenwerking in latere fasen is uitgesloten. ${ }^{56}$ Dat het accent op de voorbereidende (repressieve) fase wordt gelegd, betekent nog niet dat er daarmee ook een finaal moment met betrekking tot de gezamenlijke gegevensverwerking is gedefinieerd. Evenmin is met de genoemde passage opgehelderd wat deelnemers te doen staat wanneer er tijdens een lopend onderzoek nieuwe feiten, personen, fenomenen in beeld komen. Juist vanwege de verscheidenheid aan taken van de verschillende deelnemers kan in algemene zin zelfs worden betwijfeld of er wel een eenduidig eindmoment kan worden gedefinieerd. ${ }^{57}$ Daarom is ook niet uit te sluiten dat gegevensverwerking in een samenwerkingsverband en operationele afstemming hand in hand zullen gaan, zeker nu het gaat om op duurzame samenwerking ingerichte verbanden. Het zou goed zijn om dat met zoveel woorden te erkennen.

\subsection{Verstrekking van gegevens door samenwerkingsverbanden}

De informatie die in het samenwerkingsverband is verwerkt zal het verband uiteindelijk ook weer verlaten. Artikel 1.7 biedt de basis voor de verstrekking van gegevens aan publiek- en privaatrechtelijke deelnemers van het verband, alsmede aan derde partijen. In het eerste geval is verstrekking onder meer geoorloofd wanneer de

53. Zoals gedefinieerd in art. 1.1: '[G] personen, rechtspersonen of fenomenen, inhoudende een eerste vermoeden dat sprake is van onrechtmatige activiteiten, of voornemens daartoe, op de bestrijding waarvan het samenwerkingsverband is gericht, met inbegrip van de onderliggende gegevens uit een risicoanalyse, ten behoeve van de uitvoering van publiekrechtelijke taken of uitoefening van publiekrechtelijke bevoegdheden.'

54. Die beperking is dan weer niet te vinden in art. 2.17; de bepalingen over het LIEC en de RIEC's bieden wel ruimte voor operationele afstemming.

55. Kamerstukken I/ 2019/20, 35 447, nr. 3, p. 17, 33, 63 (MvT).

56. Ook Hirsch Ballin wijst op de praktijk, c.q. het belang van afstemming in de fase van sanctionering, vgl. M.F.H. Hirsch Ballin, 'Overbrugging van procedurele breuklijnen bij een integrale aanpak van criminaliteit', Tijdschrift voor Bijzonder Strafrecht \& Handhaving 2019, p. 163-172.

57. Vgl. M. Luchtman, J. Vervaele \& O. Jansen, Informatie-uitwisseling in het kader van het Financieel Expertise Centrum, Utrecht: Utrecht University Repository 2002, p. 83-85. 
verstrekking nodig is voor de publiekrechtelijke taakvervulling van de betrokken deelnemer, op voorwaarde dat die taak verenigbaar is met het doel van het samenwerkingsverband (art. 1.7 lid 1). ${ }^{58} \mathrm{Bij}$ verstrekking aan derde, publiekrechtelijke of private partijen gelden nog aanvullende voorwaarden (art. 1.7 lid 3). Ook strafvorderlijke gegevens mogen in beginsel worden verstrekt. ${ }^{59}$ In alle gevallen geldt dat de deelnemer die de verwerkte gegevens in het samenwerkingsverband heeft ingebracht, zich kan verzetten tegen die verstrekking. ${ }^{60}$ Wat daarmee precies wordt bedoeld blijft echter wat onduidelijk. Artikel 1.7 kan namelijk worden gezien als een exclusieve verstrekkingsgrondslag, maar ook als een geconditioneerde verstrekkingsplicht (in aanvulling op andere verstrekkingsgrondslagen). In dat laatste geval definieert dat artikellid vooral wanneer die verplichting ontstaat, maar ook niet meer dan dat.

De formulering van het artikel oogt enerzijds imperatief. Weliswaar zijn er (ruim geformuleerde en open) uitzonderingen en is de interpretatie daarvan aan de deelnemers gelaten, toch wordt er onder de genoemde condities uitgegaan van verstrekking ('ja, tenzij’). Anderzijds introduceert artikel 1.7 ogenschijnlijk geen exclusief verstrekkingenregime. Uit artikel 1.11 lid 1 blijkt namelijk dat de medewerkers van de deelnemende instanties aan hun eigen geheimhoudingsplicht gebonden blijven. ${ }^{61}$ Hetzelfde artikellid creëert een residuale geheimhoudingsplicht voor personen die betrokken zijn bij de werkzaamheden van het samenwerkingsverband en daarbij de beschikking krijgen over persoonsgegevens, maar die niet reeds uit hoofde van ambt, beroep of wettelijk voorschrift tot geheimhouding zijn verplicht. Uitzonderingen op die geheimhoudingsplicht zijn mogelijk voor zover artikel 1.7 of enig ander wettelijk voorschrift voorziet in de bevoegdheid of verplichting om de gegevens te verstrekken of voor zover de gegevensverstrekking noodzakelijk is voor het afleggen van verantwoording door een medewerker aan de deelnemer die hem heeft aangewezen voor de inzet in het samenwerkingsverband.

Naar mijn mening introduceert artikel 1.7 dan ook niet zozeer een exclusief regime, maar een op de bestaande mogelijkheden aanvullende verstrekkingsverplichting. Volgens de memorie van toelichting vereist '[d]e zinsnede "Tenzij naar het oordeel van een deelnemer zwaarwegende redenen zich daartegen verzetten worden" (...) niet in elk individueel geval een aparte beoordeling; voldoende is een algemene beoordeling [door de "verstrekkende verwerkingsverantwoordelijken"] voor de start van een project. De tenzij-clausule maakt het onder

58. Fiscale gegevens mogen niet aan private partijen worden verstrekt, zie art. 1.7 lid 6 .

59. Wel gelden dan enige aanvullende voorwaarden, zie art. 1.7 leden 3 en 7.

60. De eisen daarvoor zijn zwaarder in geval van verstrekking aan deelnemers dan aan verstrekking aan derden (art. 1.7 lid 1, resp. 2).

61. Dat is ook in lijn met art. 1.2, waarin als gezegd is te lezen dat dit wetsvoorstel een alternatief is voor bestaande mogelijkheden tot informatieuitwisseling en samenwerking. meer mogelijk om de gegevens alleen aan bepaalde partijen niet te verstrekken.' ${ }^{62}$

Het beeld van het verstrekkingenregime dat zo ontstaat is er een van overlappende cirkels. De medewerkers van de deelnemende instanties nemen deel aan het samenwerkingsverband als vertegenwoordiger van de eigen organisatie en zijn ook wat betreft de door het samenwerkingsverband verwerkte gegevens primair gebonden aan hun eigen geheimhoudingsregime. Het wetsvoorstel voorziet evenmin in functiescheidingen; de organisatie van het samenwerkingsverband is aan haar deelnemers zelf. ${ }^{63}$ Aldus ontstaan binnen de kaders van het samenwerkingsverband ook allerhande mogelijkheden tot soms zelfs binnen één persoon verenigde combinaties van taken die coördinatie van onderzoeken en afstemming van werk aanzienlijk vergemakkelijken.

\section{Beschouwing: gedeelde verantwoordelijkheid, maar gescheiden rechts- bescherming?}

\subsection{Meer van hetzelfde of toch een wezenlijke verandering?}

Uit het voorgaande komt een wat ambigu beeld naar voren. De noodzaak van wetgeving die samenwerkingsverbanden normeert is, zeker wanneer dat structurele verbanden zijn, evident. Het wetsvoorstel benadrukt dat die samenwerkingsverbanden op zichzelf geen toezichthoudende of opsporende instanties zullen zijn. Het gaat om het delen van (reeds voorhanden zijnde) informatie met het oog op een geïntegreerde, gezamenlijke aanpak. Wanneer op die manier gegevens zijn verwerkt, verlaat nieuwe (of niet bewerkte) informatie weer het samenwerkingsverband en worden door de betrokken deelnemers, waar nodig en binnen de eigen taakstellingen en bevoegdheden, nadere acties ondernomen. Dat betekent dan ook dat dergelijke opsporings- of toezichtacties uitsluitend aan de betreffende deelnemer kunnen worden toegerekend. Niet voor niets benadrukt de regering telkens weer dat dit voorstel in wezen voortbouwt op wat er allemaal al kan. De grenzen tussen toezicht en opsporing zijn, inderdaad, nooit waterdicht geweest.

In het vervolg van dit artikel wil ik bij deze positie niettemin een aantal kanttekeningen plaatsen. Ik meen dat de wijzigingen die dit voorstel met zich brengt, zeker nu het wordt gepresenteerd als een alternatief voor en niet als een vervanging van bestaande opties tot samenwerking, de bakens wel degelijk op substantiële wijze verzetten. Dit voorstel is naar mijn idee niet meer van het-

62. Kamerstukken I/ 2019/20, 35 447, nr. 3, p. 71 (MvT). Dat laatste correspondeert met art. 1.5 lid 1 op basis waarvan het ook mogelijk is om alleen aan sommige deelnemers gegevens te verstrekken; Kamerstukken I/ 2019/20, 35 447, nr. 3, p. 68 (MvT).

63. Kamerstukken I/ 2019/20, 35 447, nr. 3, p. 68 (MvT), p. 7, 83, 105 
zelfde, maar een andere benadering van samenwerking die via de introductie van een multilateraal, gezamenlijk verwerkingsdoel, verplichte verstrekkingsgrondslagen en open verstrekkingsregimes op een ' $\mathrm{ja}$, tenzij'-basis deelnemende instanties en individuele medewerkers binnen die instanties functioneel en structureel met elkaar in verbinding brengt. Hoewel uit het voorstel duidelijk wordt dat het zich primair richt op de initiële fasen van het onderzoek, zijn er bovendien geen grenzen anngebracht met betrekking tot de mogelijkheid tot samenwerking en afstemming ná die initiële fase. Een dergelijke afgrenzing lijkt ook moeilijk realiseerbaar.

Op de keper beschouwd is het narratief dan niet meer, zoals voorheen, samenwerking ten behoeve van de uitvoering van de 'eigen taak' of de hulp bij de taak van de ander (zulks uiteraard binnen de eigen wettelijke mogelijkheden), maar samenwerking ten behoeve van de verwezenlijking van een gezamenlijk doel. De omstandigheid dat de taakstellingen van de deelnemende autoriteiten niet worden veranderd, expliciteert dan weliswaar een op zichzelf goed verdedigbare rechtspolitieke keuze, maar doet niet af aan de eveneens relevante omstandigheid dat, zeker voor de bij wet geregelde samenwerkingsverbanden, de taakstellingen van de betrokken instanties structureel op elkaar worden betrokken. Dat maakt het moeilijk om het concept van de gezamenlijke verantwoordelijkheid te reserveren voor de bescherming van (persoons)gegevens; het speelt ook daarbuiten een rol. Ik denk dat dat laatste een aantal gevolgen heeft of althans moet hebben die nu onvoldoende aandacht krijgen. Ik werk dat in de volgende twee subparagrafen nader uit.

\subsection{Multilaterale gegevensverwerking en verdedigingsrechten}

Een rode draad in de jurisprudentie van het Straatsburgse Hof, waaraan ook het Luxemburgse Hof van Justitie is gebonden, is dat het wars is van formele scheidingen tussen procedures wanneer die procedures feitelijk 'suffisamment liées' zijn. De hierboven genoemde zaak Chambaz t. Zmitserland is er een goed voorbeeld van. ${ }^{64}$ In die zaak ging het als gezegd om een op strafrechtelijke leest geschoeid onderzoek van de federale belastingdienst, ${ }^{65}$ dat volgde op een kantonnaal fiscaal onderzoek waarin aan Chambaz boetes voor niet-medewerking waren opgelegd. Beide onderzoeken liepen gedurende lange tijd parallel. Het EHRM onderzoekt of de procedures op zodanige wijze met elkaar in verband zijn gebracht dat het niet-punitieve fiscale onderzoek

64. Supra noot 32; in dezelfde lijn ligt EHRM 21 april 2009, ECLI:CE:ECHR: 2009:0421JUD001923503 (Marttinen t. Finland), zie noot 33 en EHRM 3 mei 2001, ECLI:NL:XX:2001:AN6999 (J.B. t. Zwitserland).

65. Dat was de zogenaamde Abteilung Besondere Steueruntersuchungen/ BSU. Deze instantie heeft onderzoekstaken maar kan zelf geen strafvervolging instellen. $\mathrm{Na}$ afronding van haar onderzoek vordert de federale administratie dat, afhankelijk van de zaak, de kantonnale belastingdienst (die punitieve sancties kan opleggen) een procedure start, zoals in Chambaz gebeurde, of dat aangifte wordt gedaan bij de kantonnale justitie; zie M. Luchtman, Grensoverschrijdende sfeercumulatie (diss. Utrecht), Nijmegen: WLP 2007, p. 474-475. niet meer kan worden gescheiden van het strafrechtelijke voorbereidende onderzoek. Is dat inderdaad niet mogelijk, dan domineren de strafvorderlijke waarborgen het geheel van de procedures. Dat laatste is met name het geval wanneer verschillende elementen in dezelfde procedure zodanig worden gecombineerd dat het onmogelijk is de stadia van de procedure met betrekking tot een charge te onderscheiden van die met betrekking tot het niet-punitieve deel van het onderzoek. ${ }^{66}$ Uit het arrest is af te leiden dat het om meer situaties gaat dan alleen de personele unie van taken binnen een en dezelfde persoon. Ook de mate van samenwerking, de feiten die het voorwerp van onderzoek zijn en de volgtijdelijkheid van de onderzoeken blijken relevant. In zijn arrest komt het Hof tot de conclusie dat artikel 6 EVRM in het geval van Chambaz ook van toepassing was op de fiscale procedure, vanwege de overlappende taakstellingen, die inherent leiden tot een zekere overlap van het onderzoek, en de wederzijdse wettelijke informatie- en bijstandsplichten.

Het is vanwege die functionele verbondenheid dat het Hof een schending constateerde van het nemo teneturbeginsel. $\mathrm{Al}$ in een relatief vroeg stadium van het fiscale onderzoek, nog ver vóórdat het strafrechtelijke onderzoek werd gestart, kon de betrokkene niet meer uitsluiten dat dat laatste onderzoek inderdaad zou gaan volgen en dat dus zijn strafvorderlijke rechten in het gedrang zouden kunnen komen. Duidelijkheid omtrent dat laatste is, hoewel het Hof dat zelf niet zo zegt, een eis van rechtszekerheid en hangt naar mijn mening ook samen met het strafvorderlijke legaliteitsbeginsel.

De feiten in Chambaz staan natuurlijk op zichzelf. Anders dan wat de regering in dit wetsvoorstel betoogt over de functie van de samenwerkingsverbanden, liepen beide onderzoeken in Chambaz lange tijd parallel; het ging niet alleen om samenwerking in de startfase, zoals dat in samenwerkingsverbanden nu wel juist vaak aan de orde zal zijn (zie hiervoor). Gebleken was ook dat beide onderzoeken van de betrokken autoriteiten sterk op elkaar werden afgestemd en dat onderzoekswensen over en weer werden meegenomen. Toch lijken die feiten uiteindelijk niet doorslaggevend te kunnen zijn geweest; ze zijn eerder een bevestiging van 's Hofs oordeel dat Chambaz al vóór de start van het strafrechtelijke onderzoek, toen op hem druk werd uitgeoefend met bestuurlijke boetes, de mogelijkheid van strafvervolging voor belastingontduiking niet meer kon uitsluiten.

Een soortgelijke situatie kan zich gemakkelijk voordoen onder het gewijzigde wetsvoorstel. Ook wanneer de taken van de afzonderlijke deelnemers niet veranderen, beïnlloeden ze elkaar wel. Vanuit ieders afzonderlijke taakstelling wordt immers een gezamenlijk doel nagestreefd; waar nodig worden daarvoor verstrekkingsgrondslagen en geheimhoudingsregimes aangepast. Uit de tekst van het voorstel blijkt voorts de repressieve

66. EHRM 5 april 2012, ECLI:CE:ECHR:2012:0405JUD001166304 (Chambaz t. Switzerland), par. 42. 
doelstelling van de regeling. ${ }^{67}$ De gezamenlijkheid van het nagestreefde doel, dat vanuit verschillende, elkaar aanvullende invalshoeken wordt belicht, maakt dat de oorsprong van de verwerkte informatie niet altijd meer makkelijk te herleiden zal zijn. De veelheid aan verschillende - punitieve en niet-punitieve - 'interventies' die vervolgens kunnen worden gepland, de dwang die met een van die interventies op de betrokkene kan worden uitgeoefend en de onbepaaldheid van het moment waarop die samenwerking weer eindigt, beinvloedt in zo'n geval ook de rechtspositie van de betrokkene, maar nu niet alleen binnen het sectorale toepassingsveld van bijvoorbeeld de belastingwetgeving of de bescherming van de financiële sector, maar zelfs op een sector-overstijgende wijze, zoals gedefinieerd door de WGS of de daarop gebaseerde AMvB. Dit voorstel bewerkstelligt aldus dat niet alleen meer de grenzen tussen toezicht en opsporing binnen één beleidsterrein vervagen - dat is nu ook al vaak $\mathrm{zo}^{68}-$, maar betrekt bovendien meerdere beleidsterreinen op elkaar.

De vraag rijst wat de gevolgen daarvan zijn. Naar mijn idee stapt de regering, daarop terecht gewezen door de Autoriteit Persoonsgegevens, te makkelijk over die vraag heen. Samenwerkingsverbanden hebben dan wellicht niet tot doel, maar zeker tot gevolg dat voorheen formeel gescheiden procedures 'suffisamment liées' raken, en zulks niet alleen binnen de sectorale wetgeving, maar binnen de verbrede grenzen van het gezamenlijke, zwaarwegende algemene belang en dus cross-sectoraal. Anders gezegd, een niet-punitief AWR-onderzoek zal zo een Wft-boete- of strafvorderlijk onderzoek gaan beinvloeden. Daarin ligt een aanzienlijke verruiming van de reikwijdte van het nemo tenetur-beginsel besloten. Wie de strafvorderlijke waarborgen buiten die niet-punitieve procedures wil houden, zal het geheel met daarop gerichte maatregelen in procedureel opzicht weer moeten 'ontvlechten'. Wil een schending van artikel 6 EVRM (of 47 en 48 van het EU Handvest) worden voorkomen, dan kan bijvoorbeeld worden bepaald dat onder dwang verkregen wilsafhankelijk materiaal niet in het samenwerkingsverband mag worden ingebracht.

Het had niet misstaan om aan dit aspect van het voorstel nadrukkelijk aandacht te besteden, omdat het bepaald niet voortvloeit uit wat al bekend was over, kort gezegd, het snijvlak van toezicht en opsporing. Ik meen zelfs dat om de hier genoemde redenen dit wetsvoorstel ook de bestaande andere opties tot informatie-uitwisseling, die nadrukkelijk overeind worden gehouden (art. 1.2), zal gaan beinvloeden. Op voorhand is onder het huidige voorstel immers niet uit te sluiten dat van de wil afhankelijk materiaal (ook) in een samenwerkingsverband gaat worden verwerkt.

67. Vgl. de definities van 'handhavingsknelpunt', 'signaal' en 'sturingsinformatie' in art. 1.1.

68. Zie immers de hiervoor vermelde jurisprudentie van de Hoge Raad, supra noot 30 .
4.3. Onrechtmatig bewijs: osmose of autonomie van rechtsgebieden?

Een tweede dossier waarin de eigenheden van gegevensuitwisseling in samenwerkingsverbanden een rol kunnen gaan spelen is dat van het onrechtmatig bewijs, zowel ten aanzien van de onrechtmatigheidsvraag op zichzelf als ten aanzien van het daaraan te verbinden rechtsgevolg. Het huidige debat daarover wordt nadrukkelijk geplaatst in het licht van het eigene, het autonome van rechtsgebieden. In die optiek worden de vaststelling van feiten, de kwalificatie ervan en de daaraan te verbinden rechtsgevolgen, maar ook het rechtmatigheidsoordeel over onderzoekshandelingen beoordeeld in het licht van de doelstellingen en procedures van het eigen rechtsgebied. ${ }^{69}$

Tussen de regels door gaat het om meer dan alleen de autonomie van rechtsgebieden. De jurisprudentie wijst ook op een zekere, op vertrouwen berustende verdeling van taken en verantwoordelijkheden die in het verlengde van de autonomie-gedachte ligt. ${ }^{70}$ Onder deze benadering wordt ervan uitgegaan dat de bestuursrechter er in beginsel op mag vertrouwen dat het OM de regels voor doorgifte van informatie correct heeft nageleefd ${ }^{71}$ of, omgekeerd, dat de strafrechter kan vertrouwen op de rechtmatigheid van de verstrekking van gegevens door de (toen nog) NMa. ${ }^{72}$ In die lijn past ook de overweging dat bijvoorbeeld de 'uitsluiting van dergelijk bewijsmateriaal in een belastingzaak (...) in het algemeen geen aangewezen en evenredige maatregel [is] om rechtmatig optreden van de met opsporing en vervolging van strafbare feiten belaste ambtenaren te stimuleren. ${ }^{73}$ Normbevestiging en het afgeven van een signaal voor de toekomst heeft immers weinig zin als dat signaal wordt gegeven aan anderen dan tot wie het signaal moet zijn gericht, dus politie en justitie. Een soortgelijke gedachte ligt mijns inziens ook achter de vaste jurisprudentie van de Hoge Raad dat het kader van 359a Sv in beginsel alleen van toepassing is op het voorbereidende strafrechtelijke onderzoek. ${ }^{74}$ De autonomie-gedachte gaat hand in hand met en versterkt op zichzelf de procedurele scheiding van rechtsgebieden.

69. Vgl. N.G.H. Verschaeren \& V.L. Meijerman, 'Uitzonderingen op de ongebondenheid van de straf- en belastingrechter: Over onrechtmatig verkregen bewijs, onschuld en onverbindendverklaring', DD 2019/18, p. 252-269.

70. Daarover ook M.F.H. Hirsch Ballin, 'Informationele solidariteit bij terrorismebestrijding', NJB 2016, p. 1902 en van dezelfde auteur 'Overbrugging van procedurele breuklijnen bij een integrale aanpak van criminaliteit', Tijdschrift voor Bijzonder Strafrecht \& Handhaving 2019, p. 163-172. De Hoge Raad heeft zich over een dergelijk 'vertrouwensbeginsel' overigens nog niet expliciet uitgelaten, vgl. HR 5 september 2006, ECLI:NL:HR:2006:AV4122, r.o. 6.3.4.

71. CBb 9 juli 2015, ECLI:NL:CBB:2015:193.

72. Rb. Rotterdam 9 juni 2005, ECLI:NL:RBROT:2005:AT7246.

73. HR 20 maart 2015, ECLI:NL:HR:2015:643, r.o. 2.5.2.

74. M.J. Borgers \& T. Kooijmans, 'De onderzoeksfase: toezicht, controle en opsporing,' in: F. Kristen et al. (red.), Bijzonder strafrecht: Strafrechtelijke handhaving van sociaal-economisch en fiscaal recht in Nederland, Den Haag: Boom juridisch 2019, par. 4.5. Voor een concrete toepassing van die rechtspraak in de context van een samenwerkingsverband (FEC), zie Rb. Amsterdam 12 oktober 2018, ECLI:NL:RBAMS:2018:7256. 
Het is vaste rechtspraak van de Hoge Raad dat de belastingrechter, wanneer het gaat om het gebruik van strafvorderlijk onrechtmatig verkregen bewijs in fiscale zaken, een eigen taak heeft als het aankomt op de vaststelling van de feiten, zelfs wanneer die feiten dezelfde blijken te zijn als in de strafprocedure. ${ }^{75} \mathrm{Hij}$ mag ook afwijken van wat de strafrechter ter zake al aan onrechtmatigheden heeft vastgesteld, al geldt dan wel een motiveringsplicht. ${ }^{76}$ In deze lijn past mijns inziens ook dat, wanneer geconstateerde onrechtmatigheden jegens de betrokken verdachte/belastingplichtige zelf zijn begaan, ${ }^{77}$ de belastingrechter eerst zal kijken naar wat de inspecteur zelf aan informatie kon verkrijgen. ${ }^{78}$ Kon die informatie ook onder het fiscale regime worden verkregen, dan kan er in de regel van uitsluiting in fiscalibus geen sprake zijn (alternatieve causaliteit). ${ }^{79}$ In de gevallen waarin het fiscale instrumentarium tekortschiet en dus alleen het strafrechtelijk onrechtmatig bewijs kan worden gebruikt, ${ }^{80}$ zal de belastingrechter als gevolg van het 'zozeer indruist'-criterium vooral moeten beoordelen of de informatie rechtmatig door de belastingdienst werd verkregen, dan wel of die verkrijging en het verdere gebruik in overeenstemming zijn met beginselen van behoorlijk bestuur of mensenrechtelijke waarborgen.

Komt het aan op de sanctie die op de strafrechtelijke onrechtmatigheid staat, dan geldt de autonomie van en de bevoegdheidsverdeling tussen rechtsgebieden nog sterker. ${ }^{81}$ Het demonstratie- en effectiviteitsargument dat bij de toepassing van $359 \mathrm{a} \mathrm{Sv}$ in strafzaken nog tot bewijsuitsluiting zou kunnen leiden, ${ }^{82}$ speelt in fiscalibus als gezegd niet, behalve bij die categorieën normschendingen die altijd en overal tot bewijsuitsluiting moeten leiden. Dat laatste is de categorie van het 'zozeer indruist'-criterium, ${ }^{83}$ of - in strafrechtelijk jargon - van de bewijsuitsluiting als rechtsstatelijke waarborg in de meest ernstige gevallen. ${ }^{84}$ Het mag worden aangenomen dat zich hier een algemene lijn onder de hoogste Nederlandse rechters uittekent. ${ }^{85}$ Eenstemmigheid zal er ook zijn over de omstandigheid dat, wanneer het gaat om schendingen van de strafvorderlijke verdedigingsrechten, er evenmin reden is onderscheid te maken tussen de strafrechtelijke gevolgen daarvan en de gevolgen in punitieve bestuursrechtelijke sanctieprocedures. ${ }^{86}$ Een

75. HR 20 maart 2015, ECLI:NL:HR:2015:643, r.o. 2.6.2

76. HR 20 maart 2015, ECLI:NL:HR:2015:643, r.o. 2.6.3.

77. HR 20 maart 2015, ECLI:NL:HR:2015:643, r.o. 2.3.1.

78. HR 20 maart 2015, ECLI:NL:HR:2015:643, r.o. 2.3.3.

79. HR 1 juli 1992, ECLI:NL:HR:1992:ZC5028; zie ook HR 20 maart 2015, ECLI:NL:HR:2015:643, r.o. 2.3.3.

80. Denk aan de inzet van taps of de internationale strafrechtelijke rechtshulp (bankgeheim).

81. Vgl. HR 20 maart 2015, ECLI:NL:HR:2015:643, r.o. 2.6.4

82. Uitvoerig over die argumenten uiteraard G.J.M. Corstens, M.J. Borgers \& T. Kooijmans, Het Nederlands strafprocesrecht, Deventer: Wolters Kluwer 2018, p. 861-862.

83. HR 20 maart 2015, ECLI:NL:HR:2015:643, r.o. 2.5.2-2.5.3.

84. HR 19 februari 2013, ECLI:NL:HR:2013:BY5321.

85. Vgl. HvJ EU 17 december 2015, C-419/14, ECLI:EU:C:2015:832, AB 2016/393 m.nt. T. Barkhuysen, M.L. van Emmerik \& J.C. Vervorst (Web Mind Licenses $\mathrm{Kfl}$ ).

86. Aldus ook de Hoge Raad die dat oordeel evenwel beperkt tot de bestuurlijke boetes; HR 20 maart 2015, ECLI:NL:HR:2015:643. onder dwang verkregen verklaring bijvoorbeeld zal in beide procedures niet mogen worden gebruikt. Daarbuiten geldt evenwel de regel van autonomie. Wat toelaatbaar is in het ene gebied wordt naar de regels van dat gebied beoordeeld.

De bestaande jurisprudentie verdraagt zich naar mijn idee slecht met de voorstellen voor structurele, op gezamenlijke gegevensverwerking gebaseerde samenwerkingsverbanden. Natuurlijk veranderen die verbanden niet de taak van de rechter of het bewijsrecht, zoals dat in verschillende rechtsbieden tot ontwikkeling is gekomen. Maar op onderdelen - in het bijzonder wanneer het gaat om de bescherming van het recht op privacy en de strafvorderlijke verdedigingsrechten - doet een ketenbenadering inmiddels meer recht aan de realiteit dan een scenario van autonomie en alternatieve causaliteit. Zo verliest het argument van de alternatieve causaliteit - het bestuursorgaan had de gegevens ook zelf kunnen verkrijgen - veel van zijn waarde wanneer de betrokken instanties van meet af aan overleg hebben gehad over de signalen die zij kregen en de acties - 'interventies' in de woorden van de regering - die daarop zijn gevolgd. Die autoriteiten zijn immers samen op het spoor van een bepaald fenomeen gekomen en hebben samen hun acties afgestemd. Het past niet om dan te stellen dat, wanneer zich vervolgens onregelmatigheden voordoen, de gegevens ook langs andere weg hadden kunnen worden verkregen, zodat de gegevens alsnog kunnen worden gebruikt. Die weg is nu juist, en dat na gezamenlijk overleg, niet bewandeld.

Nog sterker geldt deze bedenking bij het argument dat uitsluiting van strafrechtelijk onrechtmatig bewijsmateriaal in een fiscale procedure - afgezien van 'zozeer indruist'-gevallen - hoe dan ook niet het gewenste effect kan sorteren, omdat dit signaal alleen zinvol zou zijn richting politie en justitie. Het lijkt mij precies omgekeerd te zijn. Als de betrokken autoriteiten nauw samenwerken, is er te meer reden om dat signaal wél af te willen geven, omdat het een signaal is aan alle samenwerkende partijen. Dat past ook bij het door de regering in het wetsvoorstel benadrukte uitgangspunt van de gezamenlijke (verwerkings)verantwoordelijkheid.

Vergeleken met de bestaande situatie zou zo'n gezamenlijke (of wellicht beter keten-)verantwoordelijkheid ten minste drie wijzigingen met zich brengen. Ten eerste is uitsluiting dan niet langer alleen aan de orde in gevallen die onder het 'zozeer indruist'-criterium komen. Ten tweede lijken alternatieve causaliteitsredeneringen in die gevallen minder gepast, juist omdat de autoriteiten die de gegevens wél langs rechtmatige weg hadden kunnen verkrijgen daarvoor - in onderling overleg over de 'interventies' - nu eenmaal niet hebben gekozen. Ten derde lijkt het in de rechtspraak wel teruggevonden element van vertrouwen alleen op zijn plaats wanneer er geen aanwijzingen zijn geweest van onregelmatigheden; zijn die er wel, dan past in beginsel nader onderzoek. 
Het is de vraag in hoeverre de Nederlandse rechter zich veel aan deze argumenten gelegen zal laten liggen. ${ }^{87} \mathrm{In}$ wezen gelden die argumenten immers ook nu al, al brengt het wetsvoorstel een wezenlijke, cross-sectorale verbreding aan van de thematiek. De lijn die de belastingkamer van de Hoge Raad in 2015 voorzette was naar mijn mening, wat betreft het recht op privacy, al weinig overtuigend meer, maar werd wel bestendigd. Juist op fiscaal vlak zijn toezicht en opsporing immers al heel lang niet meer van elkaar te scheiden, of het nu gaat om de vroege start van onderzoeken naar overtredingen van de belastingwet, de vervolging of de verdere afdoeningsen sanctiefase.

Ook wat betreft deze thematiek zal de meest wezenlijke verandering, als die al komt, waarschijnlijk van een Europese rechter komen. De thematiek van gegevensuitwisseling komt op heel veel manieren immers binnen de reikwijdte van het Unierecht en daarmee het EU Handvest, in het bijzonder de artikelen 7 en 8 . Uiteraard is er de AVG, maar bovendien bestaan op vrijwel alle terreinen van sociaal-economisch recht - terreinen dus waarop ook veel samenwerkingsverbanden zich begeven - EU-voorschriften die in meer algemene zin handhavingsverplichtingen aan de EU-lidstaten opleggen en bovendien meer of minder gedetailleerde voorschriften omtrent geheimhouding en informatie-uitwisseling kennen, inclusief de samenwerking met de strafrechtelijke handhavingskolom. Dat betekent dus ook dat het Hof van Justitie ter zake bevoegd is. ${ }^{88}$

Inmiddels doen zich tekenen voor waaruit blijkt dat dat Hof de problematiek van het onrechtmatig bewijs, wanneer die gelinkt is aan het recht op privacy, anders benadert dan de Hoge Raad en, vermoedelijk, ook het EHRM.$^{89}$ De meest relevante zaak is hier die van $\mathrm{Web}$ Mind Licenses/WML, waarin het ging om de vraag of de Hongaarse belastingrechter gebruik mocht maken van bewijs dat in een parallelle, nog niet afgesloten strafprocedure buiten het medeweten van de belastingplichtige werd verkregen door middel van het afluisteren van telefoongesprekken en de inbeslagname van e-mails. ${ }^{90} \mathrm{In}$ dat arrest oordeelt het Hof daarover dat het krachtens 'de artikelen 7, 47 en 52, lid 1, van het EU Handvest de taak [is] van de [belastingrechter die het navorderingsbesluit dat op dergelijke bewijzen steunt, toetst], om na te gaan of, ten eerste, het afluisteren van telefoongesprekken en de inbeslagname van e-mails bij de wet vastgestelde en in de strafprocedure noodzakelijke onderzoeksmiddelen waren en, ten tweede, het gebruik

87. In ieder geval niet in Rechtbank Amsterdam 12 oktober 2018, ECLI:NL:RBAMS:2018:7256.

88. Voor een recent voorbeeld zie HvJ EU 13 september 2018, zaak C-358/16 (UBS Europe e.a), ECLI:EU:C:2018:715.

89. Hierover ook R. van der Hulle \& R. de Bree, 'De leer van de Hoge Raad over onrechtmatig bewijs ('zozeer indruist'-criterium) door het EU Handvest op de schop?', NTER 2016, p. 304-310.

90. HvJ EU 17 december 2015, C-419/14, ECLI:EU:C:2015:832, AB 2016/393 m.nt. T. Barkhuysen, M.L. van Emmerik \& J.C. Vervorst (Web Mind Licenses $K f l$ ). De inbeslagname vond plaats zonder voorafgaande rechterlijke machtiging. De vraag is of dat de hieronder te bespreken conclusies van het Hof heeft beïnvloed. door deze dienst van de met deze middelen verkregen bewijzen eveneens bij wet was toegestaan en noodzakelijk was.' Het Hof vervolgt: 'Bovendien is het zijn taak om na te gaan of de belastingplichtige in overeenstemming met het algemene beginsel van eerbiediging van de rechten van verdediging in de administratieve procedure de mogelijkheid heeft gehad om toegang tot deze bewijzen te hebben en over deze bewijzen te worden gehoord. Indien de nationale rechter vaststelt dat deze belastingplichtige deze mogelijkheid niet heeft gehad of dat deze bewijzen in de strafprocedure zijn verkregen of in de administratieve procedure zijn gebruikt met schending van artikel 7 van het EU Handvest, moet hij deze bewijzen buiten beschouwing laten en deze beslissing nietig verklaren indien zij als gevolg daarvan grondslag mist. Deze bewijzen moeten eveneens buiten beschouwing worden gelaten wanneer deze [belasting]rechter niet gemachtigd is te controleren of zij in de strafprocedure zijn verkregen in overeenstemming met het Unierecht of wanneer hij zich niet op zijn minst ervan kan vergewissen op basis van een toetsing die reeds door een strafgerecht is verricht in een procedure op tegenspraak, dat deze bewijzen zijn verkregen in overeenstemming met dat recht.'

Het oordeel van het Hof in $W M L$ is uiteraard ook relevant voor samenwerkingsverbanden. Het is een vrij stevig oordeel dat sterk afwijkt van wat er in Nederland geldt. Het arrest betreft niet alleen het leerstuk van onrechtmatig bewijs in het licht van de artikelen 7 (en 47) EU Handvest, maar (her)definieert ook de bevoegdheidsverdeling tussen de strafrechter en bestuursrechter (althans vanuit Nederlands perspectief) en lijkt juist niet uit te gaan van de autonomie-gedachte. Integendeel, het Hof kiest voor een ketenbenadering die aansluit bij wat ik zojuist betoogde, al moet worden afgewacht of de lijn van dit arrest echt wordt doorgezet. ${ }^{91}$ Opvallend is daarbij ten eerste dat het bestaan van alternatieve, lichtere wijzen van verkrijging van de gegevens eerder een belemmering vormen voor het gebruik van de strafvorderlijke gegevens (subsidiariteit), dan een rechtvaardiging ervan, ook als zich onrechtmatigheden zouden hebben voorgedaan (alternatieve causaliteit). ${ }^{92}$ Ten tweede lijkt de beoordeling van de rechtmatigheid van de vergaring van het materiaal plaats te vinden op basis van het daarop ten tijde van de daadwerkelijke verkrijging toepasselijke rechtsregime - in casu dus het strafvorderlijke kader -, en zulks ongeacht de rechter die de rechtmatigheid uiteindelijk controleert. ${ }^{93}$ Ten derde valt op dat de bestuursrechter zich hetzij ervan moet vergewissen dat er een op tegenspraak gerichte strafrechtelijke voorziening is geweest (ik neem an dat dat

91. Ook Barkhuysen c.s. zijn niet helemaal zeker; zie supra noot 84. Er zijn wel enige tekenen die daarop wijzen. In Dzivev laat het Hof strenge nationale bewijsuitsluitingsregels met een beroep op art. 7 EU Handvest in stand; HvJ EU 17 januari 2019, C-310/16, ECLI:EU:C:2019:30 (Dzivev). Daarmee is in ieder geval duidelijk dat dergelijke nationale bepalingen niet in strijd met EU-recht zijn.

92. HvJ EU 17 december 2015, C-419/14, ECLI:EU:C:2015:832 (Web Mind Licenses $K f($ ), par. 82

93. Dat leid ik af uit par. 75-78. 
ook een kort geding kan zijn), hetzij zelf een doeltreffende voorziening in rechte moet bieden. Als klap op de vuurpijl is ten vierde de ogenschijnlijk automatische gevolgtrekking van bewijsuitsluiting een flinke stap verder dan het zeer beperkte 'zozeer indruist'-criterium.

De vraag is bovendien of, als blijkt dat de lijn van $W M L$ inderdaad navolging krijgt, het Luxemburgse Hof deze lijn ook zal doorzetten naar bijvoorbeeld de bescherming van verdedigingsrechten. Die vraag zou aan de orde kunnen komen wanneer bijvoorbeeld van de wil afhankelijk materiaal onder een bewijsrestrictie werd verkregen, maar nadien toch in een punitieve procedure wordt gebruikt. Met de zaak Chambaz werd immers duidelijk dat de procedurele verwevenheid tussen het niet-punitieve fiscale en het punitieve deel van zijn scherpe randen - lees: de toepasselijkheid van artikel 6 EVRM op het geheel - kan worden ontdaan door een gebruiksrestrictie. Onduidelijk is echter nog wat die restrictie precies betekent. ${ }^{94}$ Schending van die restrictie zal niet alleen een schending van het recht op een eerlijk proces kunnen opleveren. Ze is ook problematisch in het licht van het rechtszekerheidsbeginsel vanwege de verwachtingen die met de restrictie zijn gewekt. Wat 'gebruik' betekent wordt dan niet alleen meer gedefinieerd in het licht van het recht op een eerlijk proces, maar ook in het licht van andere belangen, als voornoemd rechtszekerheidsbeginsel of mogelijk het recht op privacy. Ook hier geldt overigens dat de Nederlandse rechter te maken heeft met een Hof van Justitie dat bij de uitleg van de relevante bepalingen uit Richtlijn een eigen, ik zou haast zeggen autonome koers vaart.

\section{Conclusie}

Samenwerkingsverbanden zijn een niet meer weg te denken fenomeen in de praktijk van de rechtshandhaving. Ze gaan uit van de gedachte dat bepaalde ongewenste maatschappelijke fenomenen het best integraal worden benaderd en waar nodig aangepakt. Uiteraard speelt de strafrechtspleging daarin ook een belangrijke rol. Het is op zichzelf goed dat er nu een voorstel ligt dat de kaders voor dergelijke verbanden verheldert en waar nodig stroomlijnt en verbreedt, ook al zouden die kaders naar mijn mening nog best wat minder vrijblijvend mogen zijn. In het voorstel 'gegevensuitwisseling in samenwerkingsverbanden' kiest de regering voor een insteek die met name is gericht op vraagstukken van gegevensverwerking. Die verwerking wordt zowel aan de inputzijde verbeterd, als aan de outputzijde, met hulp van de formulering van gezamenlijke verwerkingsdoeleinden, verplichtingen tot verstrekking van gegevens en gezamenlijke regimes voor de verwerking en, ten slotte, de verstrekking van gegevens door het verband zelf. Meermaals wordt aangegeven dat het voorstel

94. De opvatting in Nederland lijkt te zijn dat het (alleen) gaat om het gebruik als bewijs. Dat roept de vraag op wat dan de toegevoegde waarde van de restrictie is; supra noot 31. geen nieuwe autoriteiten in het handhavingslandschap introduceert, maar juist de taken en bevoegdheden van bestaande deelnemende partijen onverlet laat. De samenwerkingsverbanden zijn, als het om de gegevensverwerking gaat, een gezamenlijke verantwoordelijkheid van alle deelnemers. Samenwerkingsverbanden zijn op zichzelf echter geen opsporende of toezichthoudende instanties. Die taken blijven exclusief belegd bij zijn deelnemers.

In het voorgaande had ik kritiek op het voorstel. Bij gegevensverbanden als hier aan de orde, gaat het om veel meer dan vraagstukken van gegevensverwerking. Een belangrijk ankerpunt als het beginsel van doelbinding is in geïsoleerd verband kwetsbaar, omdat door reorganisaties van bestaande organisaties of, zoals hier, de clustering van taken onder een samenwerkingsverband dat beginsel 'van binnenuit' wordt verruimd en zo veel van zijn beschermende werking kan verliezen. Met het huidige voorstel wordt voor die verruimde verwerkingsbevoegdheid - al is dat grotendeels op vrijwillige basis - weliswaar een betere democratische basis geschapen, maar door de focus op gegevensbescherming blijven andere belangrijke waarborgen buiten beschouwing. De positie van strafrechtelijke verdedigingsrechten en procedurele rechtsbescherming zijn twee vraagstukken die in de totstandkoming van deze wet een plaats verdienen. ${ }^{95}$ Dat is zo, omdat de ontwikkeling richting geintegreerde handhaving ook een rechtsbeschermende zijde heeft die nu te veel wordt veronachtzaamd. Kort samengevat zou kunnen worden gezegd dat bij geïntegreerde handhaving ook geïtegreerde rechtsbescherming hoort.

Er zijn vooralsnog geen aanwijzingen dat die handschoen door de wetgever of de rechtspraktijk wordt opgepakt. De Nederlandse jurisprudentie over onrechtmatig bewijs leunt nog altijd sterk op de autonomie van rechtsgebieden, waaraan in procedureel opzicht een bevoegdheidsverdeling in de vorm van een soort vertrouwensregel is gekoppeld die we ook kennen uit het internationale strafrecht; de strafrechter kijkt in beginsel alleen naar het voorbereidend strafrechtelijke onderzoek, de bestuursrechter alleen naar het handelen van de bestuursrechtelijke handhavingskolom. Hier ligt naar mijn mening een schone taak voor de rechtspraktijk, waaronder ook de (strafrechts)advocatuur. Die krijgt, zo vermoed ik althans, steun uit Europese hoek. Gegevensverwerking binnen samenwerkingsverbanden is geen uitsluitend nationale aangelegenheid meer. In het voorgaande hoop ik te hebben aangetoond dat de Nederlandse jurisprudentie niet goed aansluit op die van de Europese hoven. Meerdere auteurs hebben al gewezen op het belang van het arrest in Web Mind Licenses, maar ook de Straatsburgse jurisprudentie over het nemo tene-

95. Er zijn overigens nog wel meer punten te benoemen, zoals het strafvorderlijke beginsel van interne openbaarheid (mede in het licht van art. 42 en $47 \mathrm{Hv}$ ), de politieke verantwoordelijkheid voor hetgeen in samenwerkingsverbanden plaatsvindt of, in de fase van sanctionering, het voorkomen van disproportionele bestraffing (mede in het licht van art. $49 \mathrm{Hv})$. 
tur-beginsel zal naar mijn idee beter in het voorstel moeten worden ingepast. Dat is overigens ook in het belang van de samenwerkende partijen zelf. Heeft men daarvoor geen oog, dan is voorstelbaar dat deze kwesties, die nadrukkelijk samenhangen met het idee van een gezamenlijke verantwoordelijkheid, als het ware als een boemerang terugslaan op de effectiviteitswens die aan het voorstel ten grondslag ligt. 